\title{
Integrated effect of arbuscular mycorrhizal fungi and hydrogen peroxide on the root system of trifoliate orange seedlings
}

\author{
Yong-Ming Huang, Yuan-Yuan Chen, Ying-Ning Zou*, Qiang-Sheng Wu \\ College of Horticulture and Gardening, Yangtze University, No. 88 Jingmi Road, Jingzhou, Hubei 434025, \\ China \\ *Corresponding author, e-mail: zouyingning@163.com
}

Received $10 \mathrm{Jul} 2013$

Accepted 22 Dec 2013

\begin{abstract}
The root-system architecture (RSA) is critical for plant growth and mineral absorption and is also easily affected by various abiotic and biotic factors including arbuscular mycorrhizal fungi (AMF). The present study evaluates the integrated effects of an AM fungus (Glomus versiforme) and exogenous hydrogen peroxide $(0,1$, and $100 \mu \mathrm{M})$ on mycorrhizal development, growth, RSA, and carbohydrate allocation of trifoliate orange (Poncirus trifoliata) seedlings. Root mycorrhizal colonization and number of vesicles increased significantly on application of $1 \mu \mathrm{M} \mathrm{H}_{2} \mathrm{O}_{2}$ but was notably inhibited by $100 \mu \mathrm{M} \mathrm{H}_{2} \mathrm{O}_{2}$. AMF colonization increased shoot and root fresh weight. A significant differences was seen with $1 \mu \mathrm{M} \mathrm{H}_{2} \mathrm{O}_{2}$ but not with 0 or $100 \mu \mathrm{M} \mathrm{H}_{2} \mathrm{O}_{2}$. Inoculation with AMF notably increased RSA traits, including total length, surface area, projected area, and volume, with 0 and $1 \mu \mathrm{M} \mathrm{H}_{2} \mathrm{O}_{2}$ but not with $100 \mu \mathrm{M} \mathrm{H}_{2} \mathrm{O}_{2}$. AMF significantly decreased the concentrations of sucrose and glucose in leaves treated with 0 and $100 \mu \mathrm{M} \mathrm{H}_{2} \mathrm{O}_{2}$, but notably increased the concentrations of sucrose and glucose in roots treated with 0 and $1 \mu \mathrm{M} \mathrm{H}_{2} \mathrm{O}_{2}$. The highest root sucrose allocation of AM seedlings appeared in the treatment with $1 \mu \mathrm{M} \mathrm{H}_{2} \mathrm{O}_{2}$. The results imply that a low concentration of $\mathrm{H}_{2} \mathrm{O}_{2}(1 \mu \mathrm{M})$ acted as a signal molecule to stimulate the development of RSA and AMF, whereas a high concentration of $\mathrm{H}_{2} \mathrm{O}_{2}(100 \mu \mathrm{M})$, which is regarded as a toxic molecule producing reactive oxygen species, interfered with the formation of RSA and AMs.
\end{abstract}

KEYWORDS: Poncirus trifoliata, Glomus versiforme, citrus, symbiosis

\section{INTRODUCTION}

The root-system architecture (RSA), the spatial configuration of the root system in the soil, determines the capacity of plants to uptake water and mineral nutrients from soils. The root-system architecture also possesses a high plasticity and can be affected by various abiotic and biotic factors, such as soil water availability, nutritional status, and micro-organisms ${ }^{1}$. In addition, the physiological status of plants, such as the distribution of carbon source, also regulates $\mathrm{RSA}^{2}$ causing root growth to be tightly related to the root carbon status ${ }^{3}$. The carbohydrate levels in the root system are therefore critical for an optimal RSA.

Arbuscular mycorrhizas (AMs) are a common symbiont formed between arbuscular mycorrhizal fungi (AMF) and the roots of terrestrial plants ${ }^{4}$. External hyphae of AMs can promote the ability of the host plant to absorb water and mineral nutrients from the soil, thereby regulating the metabolic activity of the host plant ${ }^{5}$. AMF also affects on the RSA increasing the root branching and root diameter ${ }^{6}$. Wu et al ${ }^{7}$ reported that the characteristics of the RSA, such as root projected area, surface area, volume, and total length increased significantly in red tangerine after inoculation with an arbuscular mycorrhizal fungus, Glomus mosseae. The branching degree of adventitious roots, primary lateral roots, and the mean diameter of roots in Prunus cerasifera increased after inoculation with $G$. intraradices but not with $G$. mosseae ${ }^{8}$. Thus certain species of AMF can have a notable impact on the RSA.

Hydrogen peroxide $\left(\mathrm{H}_{2} \mathrm{O}_{2}\right)$ is a reactive oxygen species widespread in plant tissues and can damage cells or tissues. On the other hand, $\mathrm{H}_{2} \mathrm{O}_{2}$ also plays an important role as a signal molecule in the process of plant growth and development ${ }^{9}$. Exogenous $\mathrm{H}_{2} \mathrm{O}_{2}$ also mediates the growth of primary root ${ }^{10,11}$, lateral roots, and root hairs ${ }^{12,13}$. The lateral-root formation of soya bean is strongly inhibited by $\beta$ hydroxyethyl hydrazine, while the inhibitory effect is reversed after exogenous $\mathrm{H}_{2} \mathrm{O}_{2}$ treatment ${ }^{14}$. In mung bean and cucumber, $\mathrm{H}_{2} \mathrm{O}_{2}$ could significantly promote the formation and growth of adventitious roots in vivo ${ }^{15,16}$. Interestingly, the regulation of RSA caused by exogenous $\mathrm{H}_{2} \mathrm{O}_{2}$ can be counteracted by 
the addition of exogenous ascorbic acid ${ }^{16}$. Higher concentration $(>10 \mu \mathrm{M})$ of exogenous $\mathrm{H}_{2} \mathrm{O}_{2}$ however significantly decrease total root length ${ }^{11}$. It seems that exogenous $\mathrm{H}_{2} \mathrm{O}_{2}$ could partly promote growth and development of various root structures, but the effect is dependent on the $\mathrm{H}_{2} \mathrm{O}_{2}$ concentration.

As stated before, both AMF and $\mathrm{H}_{2} \mathrm{O}_{2}$ are involved in root development, however the interactive effects between AMF and $\mathrm{H}_{2} \mathrm{O}_{2}$ are unknown. In clover roots, G. mosseae colonization significantly increased $\mathrm{H}_{2} \mathrm{O}_{2}$ concentration five weeks after sowing but it decreased seven weeks after sowing ${ }^{17}$. The structure of AMs can limit the damage of $\mathrm{H}_{2} \mathrm{O}_{2}$ in roots of Medicago truncatula, Zea mays, and Nicotinana tabacum colonized by $G$. intraradices, and the accumulation of $\mathrm{H}_{2} \mathrm{O}_{2}$ in roots occurred simultaneously with the senescence of $\mathrm{AMs}^{18}$. The burst of $\mathrm{H}_{2} \mathrm{O}_{2}$ is highly correlated with root AM colonization and arbuscules but not with vesicles or entry points ${ }^{19}$. It seems that $\mathrm{H}_{2} \mathrm{O}_{2}$ and $\mathrm{AMF}$ can influence each other. Until now, there are no reports showing an interaction between AMF and $\mathrm{H}_{2} \mathrm{O}_{2}$ on the RSA of the host plant.

The objective of the present work was to investigate the integrated effects of both AMF and $\mathrm{H}_{2} \mathrm{O}_{2}$ on the sugar contents and other traits of RSA of trifoliate orange (Poncirus trifoliata L. Raf.) seedlings.

\section{MATERIALS AND METHODS}

\section{Plant culture}

Seeds of trifoliate orange (P. trifoliata) were surface sterilized with $70 \%$ alcohol for $5 \mathrm{~min}$, rinsed five times with distilled water, and germinated at $28^{\circ} \mathrm{C}$ in the dark. The germinated seeds were sown into plastic pots $(18 \mathrm{~cm}$ upper diameter $\times 17 \mathrm{~cm}$ height $\times 13 \mathrm{~cm}$ bottom diameter) filled with autoclaved (0.11 MPa, $\left.121{ }^{\circ} \mathrm{C} 2 \mathrm{~h}\right)$ Xanthiudic ferralsol soils. At sowing, AM treated seedlings received a $40 \mathrm{~g}$ inoculum of G. versiforme (P. Karst.) S.M. Berch including the infected root segments of white clover, extra-radical hyphae, spores ( 28 spores/g), and river sand. The non-AM seedlings also received the $40 \mathrm{~g}$ autoclaved inoculum as the control. All the AM and non-AM seedlings were placed in the centre of the plastic greenhouse under ambient temperature at the College of Horticulture and Gardening, Yangtze University, Jingzhou, China, on 13 March 2011. The locations of the pots were randomized weekly.

\section{Experimental design}

The experimental treatments consisted of $2 \times 3$ factorial design with mycorrhizal inoculations (with or without $G$. versiforme) and exogenous $\mathrm{H}_{2} \mathrm{O}_{2}$ treat- ments $(0,1$, and $100 \mu \mathrm{M})$ manipulated and arranged in a completely randomized design with three replicates for each treatment to give a total of 18 pots (three seedlings per pot). The AM and non-AM seedlings were watered with 0,1 , and $100 \mu \mathrm{M}$ of $\mathrm{H}_{2} \mathrm{O}_{2}$ at an interval of seven days from June 16 to 11 , August 2011 , for a total of nine times.

\section{Parameters determinations}

The AM and non-AM plants were harvested and divided into shoots and roots, and the fresh weights were recorded on 18, August 2011.

The intact root systems were scanned with Epson Perfection V700 Photo (Seiko Epson Corp, Japan) and the images of the root systems were analysed using WinRHIZO professional 2007b (Regent Instruments Incorporated, Canada). The traits of RSA including total length, projected area, surface area, average diameter, and volume were automatically obtained. Part of 1-cm root segments were cleared by $10 \%(\mathrm{w} / \mathrm{v})$ $\mathrm{KOH}$ and stained with $0.05 \%$ (w/v) trypan blue ${ }^{20}$. The staining root segments were observed using a Leica DME bio-microscope, and the mycorrhizal colonization and the number of vesicles and entry point were calculated using the formula previously described by $\mathrm{Wu}$ et $\mathrm{al}^{21}$. The glucose and sucrose concentrations of leaves and roots were determined by the method of $\mathrm{Wu}$ et $\mathrm{al}^{22}$. In addition, root sucrose/glucose allocation was counted as the percent of root sucrose/glucose concentration against the sum of total leaf and root sucrose/glucose concentration, respectively.

\section{Statistical analysis}

Data (means $\pm \mathrm{SE}, n=3$ ) were analysed by twoway ANOVA with SAS 8.1. Percentage of mycorrhizal colonization and root sucrose/glucose allocation were arcsine-transformed prior to statistical analysis. Significant differences in means within treatments were compared with the least significant differences $(p<0.05)$.

\section{RESULTS}

No mycorrhizal colonization was recorded in the noninoculated roots. Compared to the absence of exogenous $\mathrm{H}_{2} \mathrm{O}_{2}(0 \mu \mathrm{M}), 1 \mu \mathrm{M}$ concentration of $\mathrm{H}_{2} \mathrm{O}_{2}$ significantly increased root mycorrhizal colonization by $17 \%$ and vesicles by $33 \%$ but did not affect entry points. A $100 \mu \mathrm{M}$ concentration of $\mathrm{H}_{2} \mathrm{O}_{2}$ however notably decreased root mycorrhizal colonization and vesicles, compared to 0 and $1 \mu \mathrm{M} \mathrm{H}_{2} \mathrm{O}_{2}$ (Table 1). The significant interaction between $\mathrm{H}_{2} \mathrm{O}_{2}$ and AMF occurred in the root AM colonization and entry points. 
Table 1 Effects of exogenous $\mathrm{H}_{2} \mathrm{O}_{2}$ on AM development and shoot and root fresh weights of $P$. trifoliata seedlings ${ }^{\dagger}$

\begin{tabular}{|c|c|c|c|c|c|c|}
\hline $\begin{array}{l}\mathrm{H}_{2} \mathrm{O}_{2} \\
(\mu \mathrm{M})\end{array}$ & Inoculation & $\begin{array}{c}\text { Mycorrhizal } \\
(\%)\end{array}$ & $\begin{array}{c}\text { Vesicles } \\
\text { (per cm root) }\end{array}$ & $\begin{array}{l}\text { Entry points } \\
\text { (per cm root) }\end{array}$ & $\begin{array}{l}\text { Shoot } \\
(\mathrm{g})\end{array}$ & $\begin{array}{l}\text { Root } \\
(\mathrm{g})\end{array}$ \\
\hline \multirow[t]{2}{*}{0} & Non-AMF & $0 \pm 0^{\mathrm{d}}$ & $0 \pm 0^{\mathrm{d}}$ & $0 \pm 0^{\mathrm{b}}$ & $0.888 \pm 0.023^{\mathrm{c}}$ & $0.351 \pm 0.018^{\mathrm{c}}$ \\
\hline & $\mathrm{AMF}$ & $65.1 \pm 2.8^{\mathrm{b}}$ & $9.0 \pm 0.2^{\mathrm{b}}$ & $2.0 \pm 1.0^{\mathrm{a}}$ & $0.957 \pm 0.008^{\mathrm{bc}}$ & $0.364 \pm 0.011^{\mathrm{bc}}$ \\
\hline \multirow[t]{2}{*}{1} & Non-AMF & $0 \pm 0^{\mathrm{d}}$ & $0 \pm 0^{\mathrm{d}}$ & $0 \pm 0^{\mathrm{b}}$ & $0.804 \pm 0.047^{\mathrm{d}}$ & $0.332 \pm 0.005^{\mathrm{d}}$ \\
\hline & $\mathrm{AMF}$ & $75.9 \pm 4.7^{\mathrm{a}}$ & $12.0 \pm 1.3^{\mathrm{a}}$ & $2.7 \pm 0.7^{\mathrm{a}}$ & $1.033 \pm 0.025^{\mathrm{b}}$ & $0.387 \pm 0.008^{\mathrm{a}}$ \\
\hline \multirow[t]{2}{*}{100} & Non-AMF & $0 \pm 0^{\mathrm{d}}$ & $0 \pm 0^{\mathrm{d}}$ & $0 \pm 0^{\mathrm{b}}$ & $1.129 \pm 0.036^{\mathrm{a}}$ & $0.373 \pm 0.003^{\mathrm{ab}}$ \\
\hline & $\mathrm{AMF}$ & $55.3 \pm 3.0^{c}$ & $4.0 \pm 0.5^{\mathrm{c}}$ & $2.0 \pm 1.0^{\mathrm{a}}$ & $1.163 \pm 0.084^{\mathrm{a}}$ & $0.380 \pm 0.002^{\mathrm{ab}}$ \\
\hline \multicolumn{7}{|l|}{ Significance $^{\ddagger}$} \\
\hline AMF & & $<0.001^{* *}$ & $<0.001^{* *}$ & $<0.001^{* *}$ & $<0.001^{* *}$ & $<0.001^{* *}$ \\
\hline $\mathrm{H}_{2} \mathrm{O}_{2}$ & & $<0.001^{* *}$ & $<0.001^{* *}$ & 0.579 & $<0.001^{* *}$ & $0.010^{* *}$ \\
\hline $\mathrm{AMF} \times \mathrm{H}_{2} \mathrm{O}_{2}$ & & $<0.001^{* *}$ & $<0.001^{* *}$ & 0.579 & $0.006^{* *}$ & $0.002^{* *}$ \\
\hline
\end{tabular}

\footnotetext{
'Data (mean $\pm \mathrm{SE}, n=3$ ) followed by the different letters within a column indicate significant differences among treatments at $p<0.05$.

$\doteqdot$ ANOVA $p$ values ( $p$-values at level of 0.05 or 0.01 are shown with double asterisks).
}

Application of $1 \mu \mathrm{M} \mathrm{H}_{2} \mathrm{O}_{2}$ decreased shoot and root fresh weights of non-AM seedlings but increased that of AM seedlings compared with the treatment without $\mathrm{H}_{2} \mathrm{O}_{2}$ (Table 1). Treatment with $100 \mu \mathrm{M}$ $\mathrm{H}_{2} \mathrm{O}_{2}$ significantly increased shoot and root fresh weights, irrespectively, of the mycorrhizal status in seedlings. Although AMF inoculation increased shoot and root fresh weights, the significant differences between $\mathrm{AM}$ and non-AM seedlings were only seen under $1 \mu \mathrm{M} \mathrm{H}_{2} \mathrm{O}_{2}$. Exogenous $\mathrm{H}_{2} \mathrm{O}_{2}$ and $\mathrm{AMF}$ presented a significant interaction effect on shoot and root fresh weights (Table 1).

Inoculation with $G$. versiforme improved status of RSA in trifoliate orange seedlings, especially under 0 and $1 \mu \mathrm{M} \mathrm{H}_{2} \mathrm{O}_{2}$ (Fig. 1). With 0 and $1 \mu \mathrm{M} \mathrm{H}_{2} \mathrm{O}_{2}$, the inoculated seedlings had significantly higher root length, projected area, surface area, and volume compared to non-AM control seedlings (Fig. 2a-e). Treatment with $100 \mu \mathrm{M} \mathrm{H}_{2} \mathrm{O}_{2}$ and inoculation with AMF only significantly increased root length, compared to the non-AM treatments (Fig. 2a). Root average diameter was significantly affected neither by both exogenous $\mathrm{H}_{2} \mathrm{O}_{2}$ nor the AMF (Fig. 2d).

The AMF in combination with exogenous $\mathrm{H}_{2} \mathrm{O}_{2}$ altered sucrose and glucose concentrations in the plant tissue (Fig. 3). Compared to non-AMF control, AMF treatment significantly increased leaf sucrose concentration by 7,25 , and $29 \%$ with 0,1 , and $100 \mu \mathrm{M} \mathrm{H}_{2} \mathrm{O}_{2}$ (Fig. 3a) and root sucrose concentrations by 44 and $16 \%$ with 0 and $1 \mu \mathrm{M} \mathrm{H}_{2} \mathrm{O}_{2}$ levels, respectively (Fig. 3b). Compared to non-AMF control, AMF treatment notably decreased leaf glucose concentration by 36 and $22 \%$ with 0 and $100 \mu \mathrm{M}$ $\mathrm{H}_{2} \mathrm{O}_{2}$ levels (Fig. 3c) but increased root glucose concentration by 52,73 , and $15 \%$ with 0,1 , and $100 \mu \mathrm{M}$ (a)

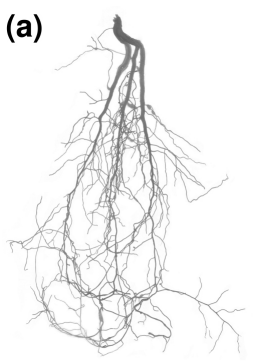

(d)

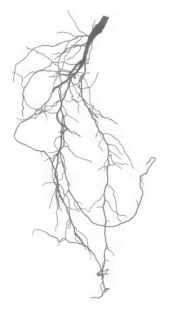

(b)

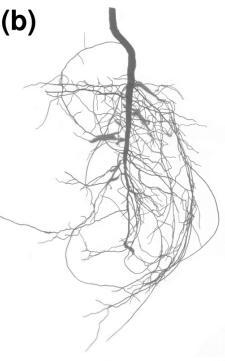

(e)

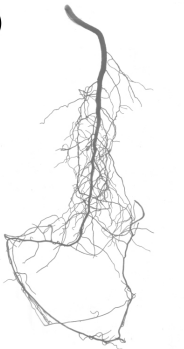

(c)
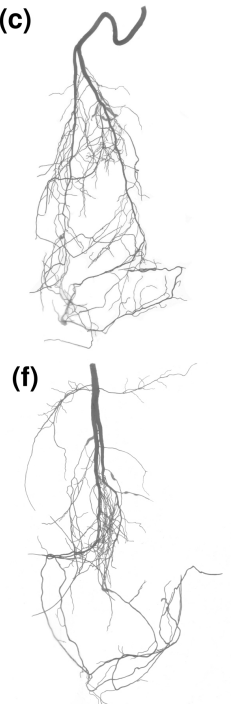

Fig. 1 Root system architecture of $P$. trifoliata seedlings inoculated with or without $G$. versiforme and treated by exogenous $\mathrm{H}_{2} \mathrm{O}_{2}$ : (a) $0 \mu \mathrm{M} \mathrm{H}_{2} \mathrm{O}_{2}+$ AMF; (b) $1 \mu \mathrm{M} \mathrm{H}_{2} \mathrm{O}_{2}+$ AMF; (c) $100 \mu \mathrm{M} \mathrm{H}_{2} \mathrm{O}_{2}+$ AMF; (d) $0 \mu \mathrm{M} \mathrm{H}_{2} \mathrm{O}_{2}-\mathrm{AMF}$; (e) $1 \mu \mathrm{M} \mathrm{H}_{2} \mathrm{O}_{2}-\mathrm{AMF}$; (f) $100 \mu \mathrm{M} \mathrm{H}_{2} \mathrm{O}_{2}-\mathrm{AMF}$.

$\mathrm{H}_{2} \mathrm{O}_{2}$, respectively (Fig. 3d). There was a significant interaction effect between AMF and $\mathrm{H}_{2} \mathrm{O}_{2}$ on the glucose and sucrose concentrations in the leaf and root (Table 2). Compared to non-AM control, AMF treatment significantly increased sucrose allocation to the root by 25,22 , and $16 \%$ (Fig. 4 a) and glucose allocation by 44,10 , and $16 \%$ under 0,1 , and $100 \mu \mathrm{M}$ $\mathrm{H}_{2} \mathrm{O}_{2}$, respectively (Fig. 4b). There was a significant interaction effect between AMF and $\mathrm{H}_{2} \mathrm{O}_{2}$ on root glucose allocation (Table 2). 


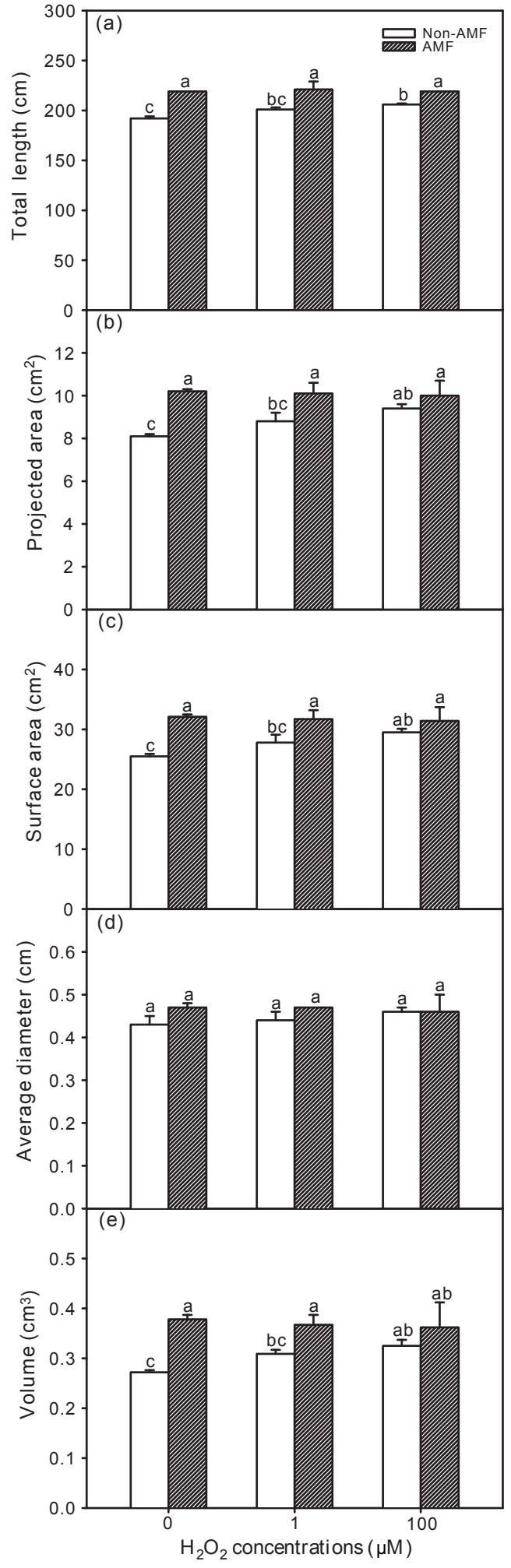

Fig. 2 Effects of exogenous $\mathrm{H}_{2} \mathrm{O}_{2}$ and arbuscular mycorrhizal fungi on traits of root system architecture of P. trifoliata seedlings. Data (mean $\pm \mathrm{SE}, n=3$ ) marked by different letters are significantly different at $p<0.05$.

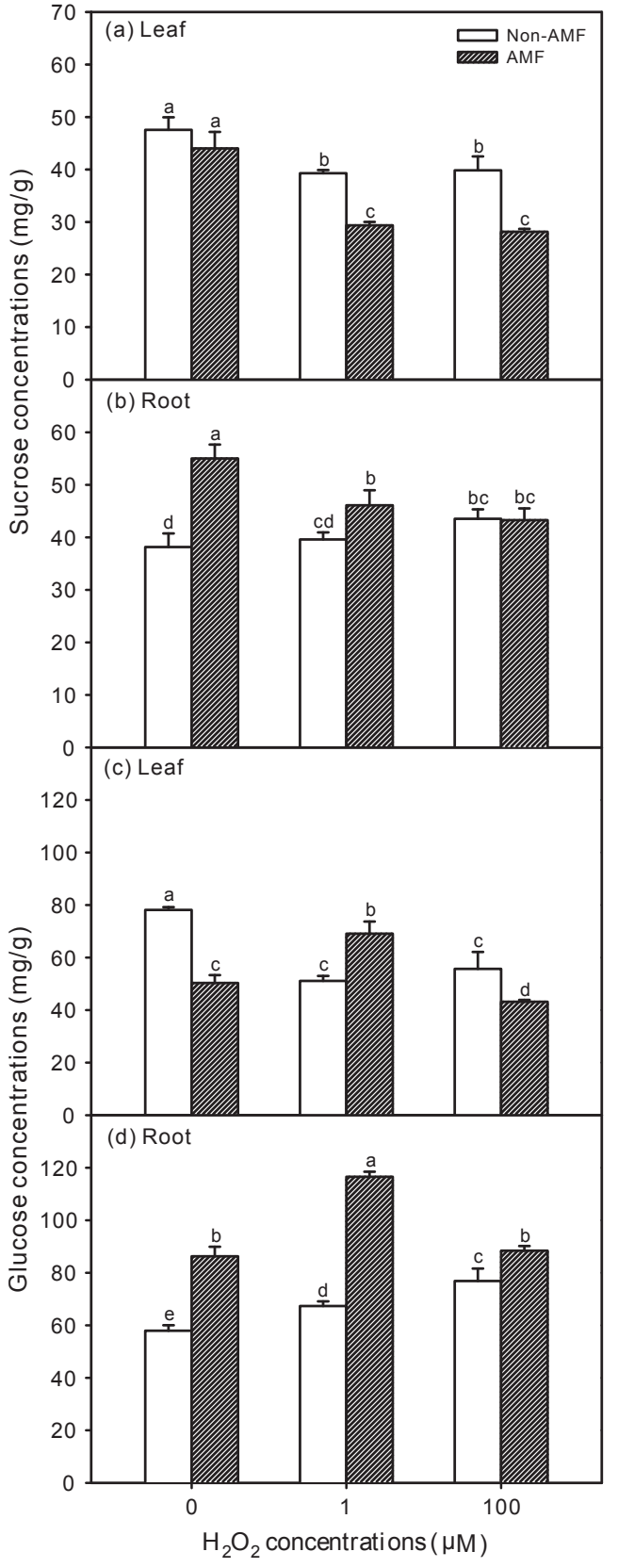

Fig. 3 Effects of exogenous $\mathrm{H}_{2} \mathrm{O}_{2}$ and arbuscular mycorrhizal fungi on glucose and sucrose concentrations of P. trifoliata seedlings. Data (mean $\pm \mathrm{SE}, n=3$ ) marked by different letters are significantly different at $p<0.05$.

\section{DISCUSSION}

Symbioses between plants and AMF are mediated by signal exchanges, such as flavonoid compounds, polyamines, Nod factor, and phenolic compounds ${ }^{23}$. Our results show that exogenous $\mathrm{H}_{2} \mathrm{O}_{2}$ altered the root mycorrhizal colonization and the number of vesi- 
Table 2 Significance of the integrated effects of AMF and exogenous $\mathrm{H}_{2} \mathrm{O}_{2}$ on RSA traits and carbohydrate concentrations of $P$. trifoliata seedlings!

\begin{tabular}{lccc}
\hline Indexes & AMF & $\mathrm{H}_{2} \mathrm{O}_{2}$ & $\mathrm{AMF} \times \mathrm{H}_{2} \mathrm{O}_{2}$ \\
\hline Root length & $<0.001^{* *}$ & 0.160 & 0.256 \\
Root projected area & $0.001^{* * *}$ & 0.348 & 0.137 \\
Root surface area & $0.001^{* *}$ & 0.353 & 0.140 \\
Average root diameter & 0.086 & 0.661 & 0.343 \\
Root volume & $<0.001^{* *}$ & 0.528 & 0.135 \\
Leaf sucrose & $<0.001^{* *}$ & $<0.001^{* *}$ & $0.009^{* *}$ \\
Root sucrose & $<0.001^{* *}$ & $0.033^{* *}$ & $<0.001^{* *}$ \\
Leaf glucose & $0.001^{* *}$ & $<0.001^{* *}$ & $<0.001^{* *}$ \\
Root glucose & $<0.001^{* *}$ & $<0.001^{* *}$ & $<0.001^{* *}$ \\
Root sucrose allocation & $<0.001^{* *}$ & $<0.001^{* *}$ & 0.500 \\
Root glucose allocation & $<0.001^{* *}$ & $<0.001^{* *}$ & $<0.001^{* *}$ \\
\hline
\end{tabular}

$\dagger$ ANOVA $p$ values ( $p$-values at level of 0.05 or 0.01 are shown with double asterisks).

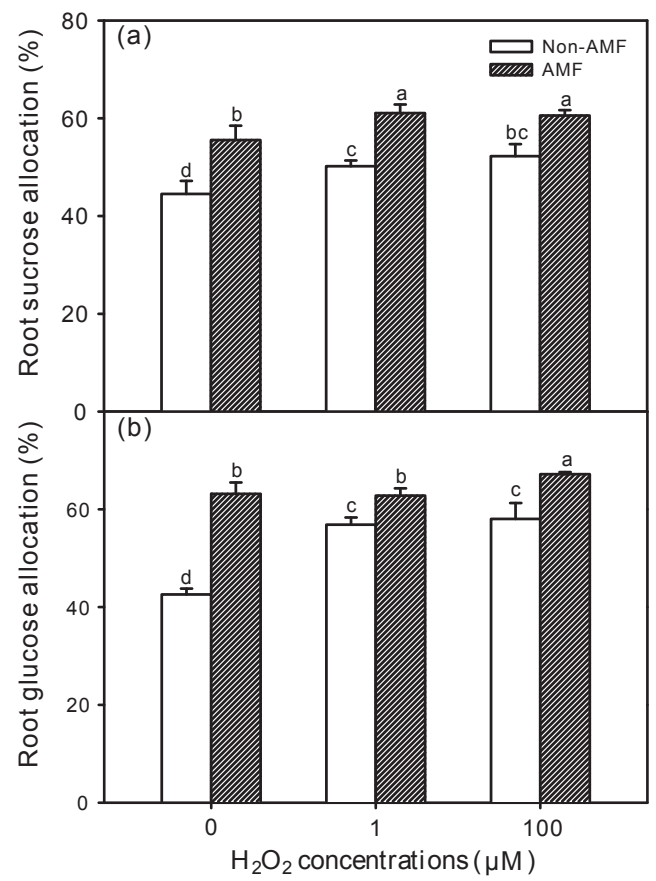

Fig. 4 Effects of exogenous $\mathrm{H}_{2} \mathrm{O}_{2}$ and arbuscular mycorrhizal fungi on (a) root sucrose and (b) root glucose allocation of $P$. trifoliata seedlings. Data (mean $\pm \mathrm{SE}$, $n=3$ ) marked by different letters are significantly different at $p<0.05$.

cles of the G. versiforme-inoculated trifoliate orange seedlings. This effect was dependent on $\mathrm{H}_{2} \mathrm{O}_{2}$ levels with $1 \mu \mathrm{M} \mathrm{H} \mathrm{H}_{2} \mathrm{O}_{2}$ increasing colonization and the number of vesicles and with $100 \mu \mathrm{M} \mathrm{H}_{2} \mathrm{O}_{2}$ decreasing colonization compared to the $0 \mu \mathrm{M} \mathrm{H}_{2} \mathrm{O}_{2}$ treatment. It seems that low concentration of $\mathrm{H}_{2} \mathrm{O}_{2}$ might act as a signal molecule in mycorrhizal development while high concentration of $\mathrm{H}_{2} \mathrm{O}_{2}$ is a toxic reactive oxygen species that damages mycorrhizal development.

In this study, inoculation with $G$. versiforme improved RSA traits (root length, projected area, surface area, and volume, except average diameter) of trifoliate orange seedlings under $0 \mu \mathrm{M} \mathrm{H}_{2} \mathrm{O}_{2}$ conditions, which is in agreement with the report on trifoliate orange by $\mathrm{Wu}$ et $\mathrm{al}^{24}$. The RSA improvement due to mycorrhization was linked to the improvement of nutrition (e.g., phosphorus) uptake, the regulation of endogenous polyamines ${ }^{7,25}$, and endogenous hormone synthesis, transport, or sensitivity ${ }^{26}$. Compared to treatment of $0 \mu \mathrm{M} \mathrm{H}_{2} \mathrm{O}_{2}, 1 \mu \mathrm{M}$ concentration of $\mathrm{H}_{2} \mathrm{O}_{2}$ notably altered RSA, as low concentrations of $\mathrm{H}_{2} \mathrm{O}_{2}$ are postulated to modulate abscisic acid signalling during root growth and development ${ }^{27}$. On the other hand, $\mathrm{H}_{2} \mathrm{O}_{2}$ itself might promote cell division, thus inducing cell elongation process ${ }^{28}$. In the present work, non-mycorrhizal seedlings presented a significantly higher total root length, projected area, surface area, and volume when treated with $100 \mu \mathrm{M} \mathrm{H}_{2} \mathrm{O}_{2}$ level compared to $0 \mu \mathrm{M} \mathrm{H}_{2} \mathrm{O}_{2}$ level. However, there were no significant differences in RSA traits between AM seedlings treated with 0 and $100 \mu \mathrm{M} \mathrm{H}_{2} \mathrm{O}_{2}$. This suggests that the presence of AMs reduced the adverse effects of high levels of $\mathrm{H}_{2} \mathrm{O}_{2}$ on RSA. AMF however were not able to improve RSA under $100 \mu \mathrm{M} \mathrm{H}_{2} \mathrm{O}_{2}$ conditions, the toxic effects of $\mathrm{H}_{2} \mathrm{O}_{2}$ on cell growth may also hinder the mycorrhizal effect.

The present study showed that the AMF inoculation decreased leaf sucrose concentration with 1 and $100 \mu \mathrm{M} \mathrm{H}_{2} \mathrm{O}_{2}$ but increased root sucrose concentration with 0 and $1 \mu \mathrm{M} \mathrm{H}_{2} \mathrm{O}_{2}$, thereby increasing sucrose allocation to the root in AM seedlings. The result agrees with a previous study ${ }^{29}$ reporting an increment of the root sucrose allocation in the Prunus persica plants colonized by G. versiforme. The alteration of carbohydrates might be related to the activities of sucrose-cleaving enzymes induced by mycorrhization ${ }^{30}$. It is well known that carbohydrates, particularly sucrose are substrates for metabolism that strongly impact root development ${ }^{31}$. AMs would generally consume $10-20 \%$ of net carbon from photosynthesis of host plants and are prioritized to absorb small molecule carbohydrates, such as glucose ${ }^{32,33}$. As a result, higher root sucrose content and higher root sucrose allocation in AM seedlings under low concentration $\mathrm{H}_{2} \mathrm{O}_{2}$ conditions would have a potential role in root morphogenesis. In the present study, the mycorrhizal trifoliate orange seedlings also recorded significant lower leaf glucose concentration and higher root glucose concentration, regardless of exogenous $\mathrm{H}_{2} \mathrm{O}_{2}$ levels. Since AMs prefer to absorb 
glucose, a higher root glucose concentration under mycorrhization could provide a better sugar supply for the AMF development.

Thus AMs in combination with application of exogenous $1 \mu \mathrm{M} \mathrm{H}_{2} \mathrm{O}_{2}$ could stimulate the root sucrose and glucose allocation, to maintain the development of AMs and the root systems.

Acknowledgements: This work was supported by the National Natural Science Foundation of China (Grant no. 31101513). We are grateful to the referee for their valuable comments on this manuscript.

\section{REFERENCES}

1. Osmont KS, Sibout R, Hardtke C (2007) Hidden branches: developments in root system architecture. Annu Rev Plant Biol 58, 93-113.

2. Freixes S, Thibaud MC, Tardieu F, Muller B (2002) Root elongation and branching is related to local hexose concentration in Arabidopsis thaliana seedlings. Plant Cell Environ 25, 1357-66.

3. Walter A, Nagel KA (2006) Root growth reacts rapidly and more pronounced than shoot growth towards increasing light intensity in tobacco seedlings. Plant Signal Behav 1, 225-6.

4. Smith SE, Read DJ (2008) Mycorrhizal symbiosis, 3rd edn, Academic, New York.

5. Turnau K, Haselwandter K (2002) Arbuscular mycorrhizal fungi, an essential component of soil microflora in ecosystem restoration. In: Gianinazzi S, Schuepp H, Barea JM, Haselwandter K (eds) Mycorrhizal Technology in Agriculture, Birkhäuser Verlag, Basel, pp 137-49.

6. Berta G, Fusconi A, Hooker JE (2002) Arbuscular mycorrhizal modifications to plant root systems. In: Gianinazzi S, Schuepp H, Barea JM, Haselwandter K (eds) Mycorrhizal Technology in Agriculture, Birkhäuser Verlag, Basel, pp 71-101.

7. Wu QS, He XH, Zou YN, Liu CY, Xiao J, Li Y (2012) Arbuscular mycorrhizas alter root system architecture of Citrus tangerine through regulating metabolism of endogenous polyamines. Plant Growth Regul 68, 27-35.

8. Berta G, Trotta A, Fusconi A, Hooker JE, Munro M, Atkinson D, M, Giovannetti M, Mprini S, Fortuna P, Tisserant B, Gianinazzi-Pearson V, Glaninazzi S (1995) Arbuscular mycorrhizal induced changes to plant growth and root system morphology in Prunus cerasifera. Tree Physiol 15, 281-93.

9. Deng XP, Cheng YJ, Wu XB, Kwak SS, Chen W, Eneji AE (2012) Exogenous hydrogen peroxide positively influences root growth and exogenous hydrogen peroxide positively influences root growth and metabolism in leaves of sweet potato seedlings. Aust J Crop Sci 6, 1572-8.

10. Zolla G, Heimer YM, Barak S (2010) Mild salinity stimulates a stress-induced morphogenic response in Arabidopsis thaliana roots. J Exp Bot 61, 211-24.

11. Dunand C, Crèvecoeur M, Penell C (2007) Distribution of superoxide and hydrogen peroxide in Arabidopsis root and their influence on root development: possible interaction with peroxidases. New Phytol 174, 332-41.

12. Carol RJ, Dolan L (2006) The role of reactive oxygen species in cell growth: lessons from root hairs. $J$ Exp Bot 57, 1829-34.

13. Jiang J, Su M, Wang L, Jiao C, Sun Z, Cheng W, Li F, Wang C (2012) Exogenous hydrogen peroxide reversibly inhibits root gravitropism and induces horizontal curvature of primary root during grass pea germination. Plant Physiol Biochem 53, 84-93.

14. Su GX, Zhang WH, Liu YL (2006) Involvement of hydrogen peroxide generated by polyamine oxidative degradation in the development of lateral roots in soybean. J Integr Plant Biol 48, 426-32.

15. Li SW, Xue LG, Xu SJ, Feng HY, An LZ (2009) Hydrogen peroxide acts as a signal molecule in the adventitious root formation of mung bean seedlings. Environ Exp Bot 65, 63-71.

16. Li SW, Xue LG, Xu SJ, Feng HY, An LZ (2007) Hydrogen peroxide involvement in formation and development of adventitious roots in cucumber. Plant Growth Regul 52, 173-80.

17. Zhang RQ, Zhu HH, Zhao HQ, Yao Q (2013) Arbuscular mycorrhizal fungal inoculation increases phenolic synthesis in clover roots via hydrogen peroxide, salicylic acid and nitric oxide signaling pathways. J Plant Physiol 170, 74-9.

18. Fester T, Hause G (2005) Accumulation of reactive oxygen species in arbuscular mycorrhizal roots. Mycorrhiza 15, 373-9.

19. Wu QS, Zou YN (2009) Mycorrhiza has a direct effect on reactive oxygen metabolism of drought-stressed citrus. Plant Soil Environ 55, 436-42.

20. Phillips JM, Hayman DS (1970) Improved procedures for clearing roots and staining parasitic and vesiculararbuscular mycorrhizal fungi for rapid assessment of infection. Trans Br Mycol Soc 55, 158-61.

21. Wu QS, Xia RX, Zou YN (2008) Improved soil structure and citrus growth after inoculation with three arbuscular mycorrhizal fungi under drought stress. Eur J Soil Biol 44, 122-8.

22. Wu QS, Peng YH, Zou YN, Liu CY (2010) Exogenous polyamines affect mycorrhizal development of Glomus mosseae-colonized citrus (Citrus tangerine) seedlings. Sci Asia 36, 254-8.

23. Harrison MJ (2005) Signaling in the arbuscular mycorrhizal symbiosis. Annu Rev Microbiol 59, 19-42.

24. Wu QS, Zou YN, He XH, Luo P (2011) Arbuscular mycorrhizal fungi can alter some root characters and physiological status in trifoliate orange (Poncirus trifoliata L. Raf.) seedlings. Plant Growth Regul 65, 273-8.

25. Padilla IMG, Encina CL (2005) Changes in root morphology accompanying mycorrhizal alleviation of 
phosphorus deficiency in micropropagated Annona cherimola Mill. plants. Sci Hort 106, 360-9.

26. Hodge A, Berta G, Doussan C, Merchan F, Crespi M (2009) Plant root growth, architecture and function. Plant Soil 321, 153-87.

27. Bai L, Zhou Y, Zhang XR, Song CP, Cao MQ (2007) Hydrogen peroxide modulates abscisic acid signaling in root growth and development in Arabidopsis. Chin Sci Bull 52, 1142-5.

28. Hameed A, Farooq S, Iqbal N, Arshad R (2004) Influence of exogenous application of hydrogen peroxide on root and seedlings growth on wheat (Triticum aestivum L.). Int J Agr Biol 6, 366-9.

29. Wu QS, Li GH, Zou YN (2011) Improvement of root system architecture in peach (Prunus persica) seedlings by arbuscular mycorrhizal fungi, related to allocation of glucose/sucrose to root. Not Bot Horti Agrobot ClujNapoca 39, 232-6.

30. Wu QS, Zou YN, Huang YM, Li Y, He XH (2013) Arbuscular mycorrhizal fungi induce sucrose cleavage for carbon supply of arbuscular mycorrhizas in citrus genotypes. Sci Hort 160, 320-5.

31. Koch EK, Ying Z, Wu Y, Avigne WT (2000) Multiple paths of sugar-sensing and a sugar/oxygen overlap for genes of sucrose and ethanol metabolism. J Exp Bot $\mathbf{5 1}$, 417-27.

32. Bago B, Pfeffer PE, Abubaker J, Jun J, Allen JW, Brouillette J, Douds DD, Lammers PJ, Shachar-Hill Y (2003) Carbon export from arbuscular mycorrhizal roots involves the translocation of carbohydrate as well as lipid. Plant Physiol 131, 1496-507.

33. Schubert A, Allara P, Morte A (2004) Cleavage of sucrose in roots of soybean (Glycine max) colonized by an arbuscular mycorrhizal fungus. New Phytol 161, 495-501. 